\title{
1-(2－Tetrahydrofuryl)-5-Fluorouracil を主菜とする制窑郕についで1
}

\author{
新光 毅, 平野善信*2, 松永幾郎*3 \\ 国立療箩所兵庫中央病院薬荗部*2 \\ 国立大阪病院薬剤部*3
}

\section{Anticancer Agents Containing 1-(2-Tetrahydrofuryl) -5-Fluorouracil*1}

\author{
TAKESHI NIIMITSU and YOSHINOBU HIRANO*2, \\ IKURO MATSUNAGA*3
}

\author{
Pharmacy, Hyogo Central Hospital, National Sanatorium*2 \\ Pharmacy, National Osaka Hospital*3
}

(Received February 4, 1978)

\begin{abstract}
In preparation for determination of bioavailability of drugs, in vitro disintegration test and dissolution test were conducted on 7 brands of oral anticancer agents containing 1-(2-tetra hydrofuryl)-5-fluorouracil, so as to compare their equivalency. Disintegration test was carried out in conformity with J. P. IX and dissolution test was made with sartorius solubility simulator. Three test fluids were used : (1) 1st fluid (artificially prepared gastric solution, $\mathrm{pH}$ 1.2); (2) 2nd fluid (artificially prepared intestinal solution, $\mathrm{pH} 7.5$ ); (3) water (pH 5.6). Significant difference (not less than $5 \%$ ) of the disintegration time was observed among brands and test fluids; as for $50 \%$ dissolution time, significant difference (not less than $5 \%$ ) was observed among brands and not among test fluids.
\end{abstract}

\section{緒}

医薬品には同一成分，同一含量，同一剂形で 2 社以上 の銘柄が収載されているものも少なくない.

近年医薬品の生物学的等価性が重要視されるようにな ってきたが，これら医薬品の各々がすべて同等の薬効を 示すとは限らない. 著者らは今回, 経口制癌剤で 1-(2tetrahydrofuryl)-5-fluorouracil を主薬とした同一成 分, 同一含量, 同一剂形の製剂 7 社をとりあげ, in vitro そおいてこれらの等価性を知る上での一つの目安となる 崩壇試験並びに溶出試験を行い, 得られた実験成績につ いて検討を加えたので報告する。

*1 本報を「カプセル剂の溶出に関する研究」(第 1 報) とする。

*2 兵庫県三田市大原; Ohara, Sanda-shi, Hyogo, 669-13 Japan

*3 大阪市東区法円坂町 2-1；2-1, Hoensaka-cho, Higashi-ku, Osaka, 540 Japan
実 匰 の 部

\section{1. 実験試料}

試料として表 1 の 7 社の 1- (2-tetrahydrofuryl)-5fluorouracil を主薬とするカプセル阂を選び崩壊試験並 びに溶出試験に供した。

表 1. 試 料

\begin{tabular}{cll}
\hline \hline 商品名 & Lot No & メーカー \\
\hline F & GC6Z03 & T A \\
M & KF01 & T T \\
R & 2 G011 & K S \\
H & L6127A & M T \\
T & 7B78C & T H \\
B & BC10 & M F \\
I & ZWC073 & T R \\
\hline
\end{tabular}

2. 位用轿器

日局 9 崩壞試験器. 
Sartorius Solubility Simulator(Sartorius Membran Filter $\mathrm{GmbH}$ ).

島津 UV-300 自記分光光度計 UV-300オートフローセ ルュニット (AFU - 2Type).

\section{3. 試験液}

日局第 1 液（pH=1.2）. また制癌剤を対象とした実 験であるため, 胃を摘出した場合や胃内の $\mathrm{pH}$ が通常よ りも高い場合に用いられることを考慮し, 参考のために 試験液として日局第 2 液 $(\mathrm{pH}=7.5)$, 水 $(\mathrm{pH}=5.6)$ につ いても実験した。

\section{4. 試験方法}

1）崩壊試験法 日局 9 の一般試験法崩壊試験法カプ セル斉の規定に従って実施した. 各試料ともカプセル 6 個についての崩壊時間を測定し, その平均値を測定結果 とした。

2) 溶出試験法 Sartorius Solubility Simulator の 溶解槽に直径 $8 \mathrm{~mm}$ のプラスチック製ビーズ玉 $85 \mathrm{~g}$ 及び 試験液 $100 \mathrm{~m}$ lを入れ, $37 \pm 2^{\circ}$ の恒温状態にし, 採取量を $2.5 \mathrm{~m} \ell$, サンプリング間隔を 2 分間にセットする. 試料 1 カプセルを溶解槽に入れ直ちに本機を始動させる.なお 各試料につき 1 カプセルずつ 3 回試験を行い, その平均 値を測定結果とした。

3）定量法 溶出液中の 1-(2-tetrahydrofuryl)-5fluorouracil の定量は次のように行った.

各時間毎の溶出液をその時に供した試験液で 100 倍に 希釈した後,オートセルニニットを設置したUV-300自記 分光光度計で測定する ${ }^{a)}$. 別に 1-(2-tetrahydrofuryl) -5-fluorouracil の標準品b) 約 $100 \mathrm{mg}$ を精科し溶出液を希 釈したのと同じ試験液で $100 \mathrm{~m} \ell$ とし，100 倍希釈した後 同様に操作する.

a) UV-300自記分光光度計測定条件

波 長 : $\lambda_{1}=271 \mathrm{~nm}, \lambda_{2}=330 \mathrm{~nm}$

$$
\text { スリット : } 2
$$$$
\text { レン ジ: } 0 \sim 2 \mathrm{ABS}
$$

b) 1-(2-tetrahydrofuryl)-5-fluorouracil 標準品 1-(2-tetrahydrofuryl)-5-fluorouracil をエタノー ルで再結晶し，105で 4 時間乾燥したときに以下の 条件を満たすものを標準品とした.

$$
\mathrm{mp}: \text { : } 168 \sim 169^{\circ}
$$

含量 : $99 \%$

UV極大吸収波長 : $271 \mathrm{~nm}$

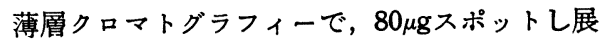
開したとき 1 スポット

\section{結 果の 部}

\section{1. 各社製剂のカプセルの外锶}

今回実験に供した各種銘柄の外観（大きさと色）をま とめてみると表 2-1,2-2 に示すように大きさは 1 号カプ セルがほとんどであり，色については橙色を基調とした ものがほとんどであった。このように外観については各 銘柄とも同じような傾向を示している.

表 2-1. 各銘柄の外観（大きさ）

\begin{tabular}{ccc}
\hline サイ $ス ゙ ~$ & 容 積 & 銘 柄 数 \\
\hline 1 号 & $0.5 \mathrm{~m} \ell$ & 5 \\
2 号 & $0.4 \mathrm{~m} \ell$ & 2 \\
\hline
\end{tabular}

\begin{tabular}{|c|c|c|}
\hline キャップ & ボデー & 銘 柄 数 \\
\hline 赤味橙色 & 白色 & 3 \\
\hline 淡赤橙色 & 白色 & 1 \\
\hline 白色 & 白色 & 1 \\
\hline 橙 色 & 白色 & 2 \\
\hline
\end{tabular}

表 2-2. 各銘柄の外観 (色)

\section{2. 崩壊試験}

各銘柄とも崩壊試験の結果はすべて日局 9 の規定に適 合した．肉眼による観察では，まずカプセルの両端が開 口し内容物が放出される. 中にはカプセルが崩壊しても 内容物が塊状になったものもみられた．各銘柄のそれぞ れの試験液による崩壊時間は表 3 に示す通りである.

表 3. 各試験液による崩壊時間

\begin{tabular}{clll}
\hline \hline 商 品名 & 第 1 液 & 第 2 液 & 水 \\
\hline $\mathrm{F}$ & 4 分 & 5 分 & 6 分 \\
$\mathrm{M}$ & 4 & 6 & 8 \\
$\mathrm{R}$ & 4 & 5 & 7 \\
$\mathrm{H}$ & 3 & 4 & 4 \\
$\mathrm{~T}$ & 5 & 5 & 6 \\
$\mathrm{~B}$ & 4 & 4 & 5 \\
$\mathrm{I}$ & 4 & 4 & 5 \\
\hline
\end{tabular}

銘柄間及び試験液間について二元配置法（くり返しの ない場合）により有意水準 $5 \%$ にて分散分析を行ったと ころ,

銘柄間 : $F_{1}=4.45>f_{0}=3.00$ 自由度 $(6,12)$

試験液間 : $F_{2}=14.62>f_{1}=3.89$ 自由度 $(2,12)$ となり, いずれの場合にも有意差が認められた。

\section{3. 溶出試験}

各試験液での溶出曲線を図 1，2，3に，また $50 \%$ 溶 
出時間を表 4 亿示す.

試験液を問わずH, I の溶出が早く, B, T は中間であ り， R, M, F は遅い部類であった。

表 4. 各銘柄の $50 \%$ 溶出時間

\begin{tabular}{ccccc}
\hline 層品名 & 第 1 液 & 第 2 液 & 水 \\
\hline $\mathrm{F}$ & 17 & 分 & 16 分 & 12 分 \\
$\mathrm{M}$ & 13 & 14.5 & 13.5 \\
$\mathrm{R}$ & 14 & 16.5 & 13.5 \\
$\mathrm{H}$ & 6 & 6 & 7 \\
$\mathrm{~T}$ & 9 & 8.5 & 11 \\
$\mathrm{~B}$ & 11 & 11 & 11 \\
$\mathrm{I}$ & 7 & 10 & 9.5 \\
\hline
\end{tabular}

50\%溶出時間について銘柄間及び試験液間に有意差が あるかどらかを二元配置法（くり返しのない場合）によ り有意水準 $5 \%$ にて分散分析を行ったところ，

銘柄間 : $F_{1}=13.76>f_{0}=3.00$, 自由度 $(6,12)$

試験液間 : $F_{2}=0.44<f_{1}=3.89$, 自由度 $(2,12)$ となり，銘柄間には50\%溶出時間に有意差が認められた が，試験液間については有意差が認められなかった。

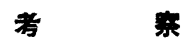

医薬品（錠昘，カプセル斉等）の Bioavailabilityを in vitroに拈いて推察する手段としていろいろなモデル が考えられているが, 崩壊試験, 溶出試験のみでその相 関を求めることは困難である. 本来血中濃度, 尿中排浛 等を測定するわけであるが, 本実験のように製凧間の比.

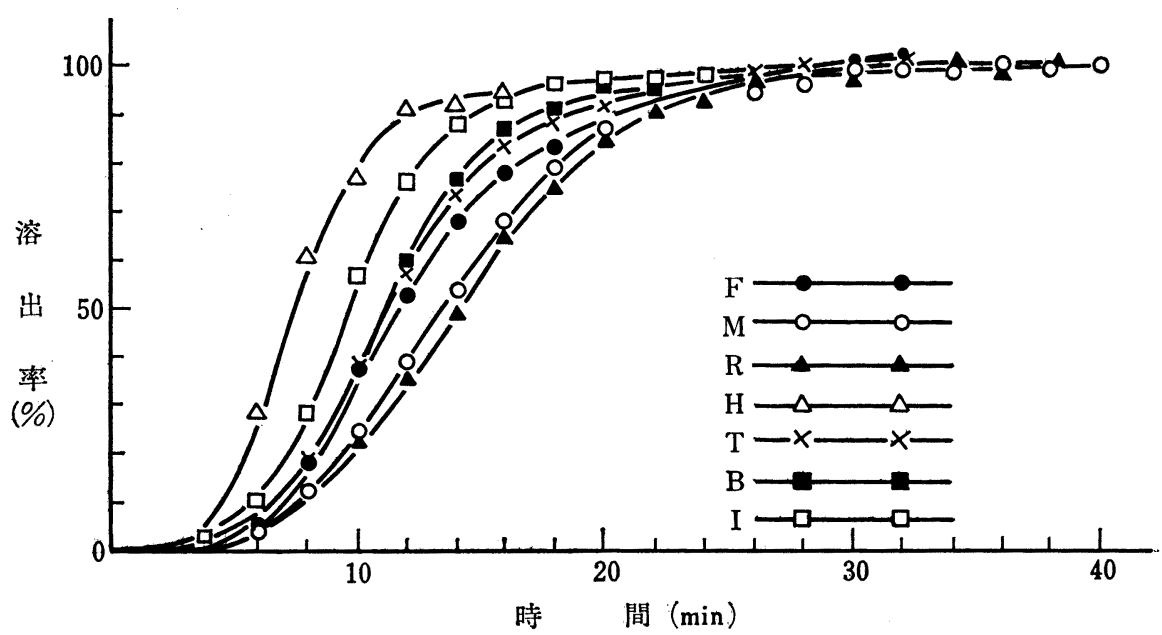

図 1. 第 1 夜（pH 1.2）における各銘柄の溶出曲線

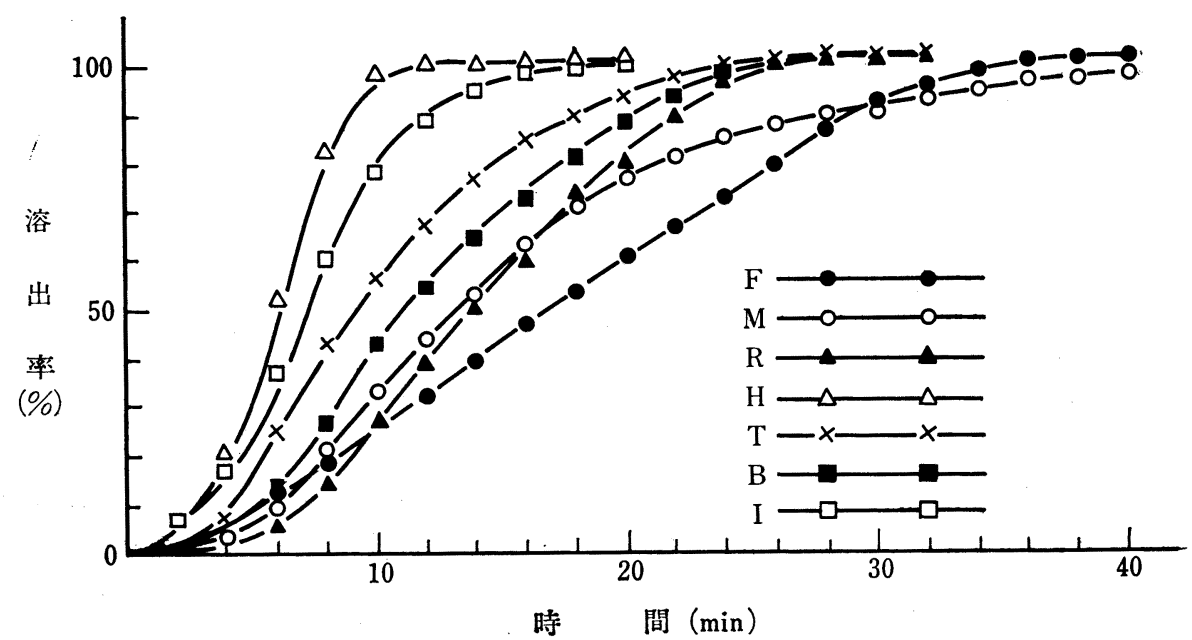

図 2. 第 2 夜 $(\mathrm{pH} 7.5)$ における各銘柄の溶出曲線 


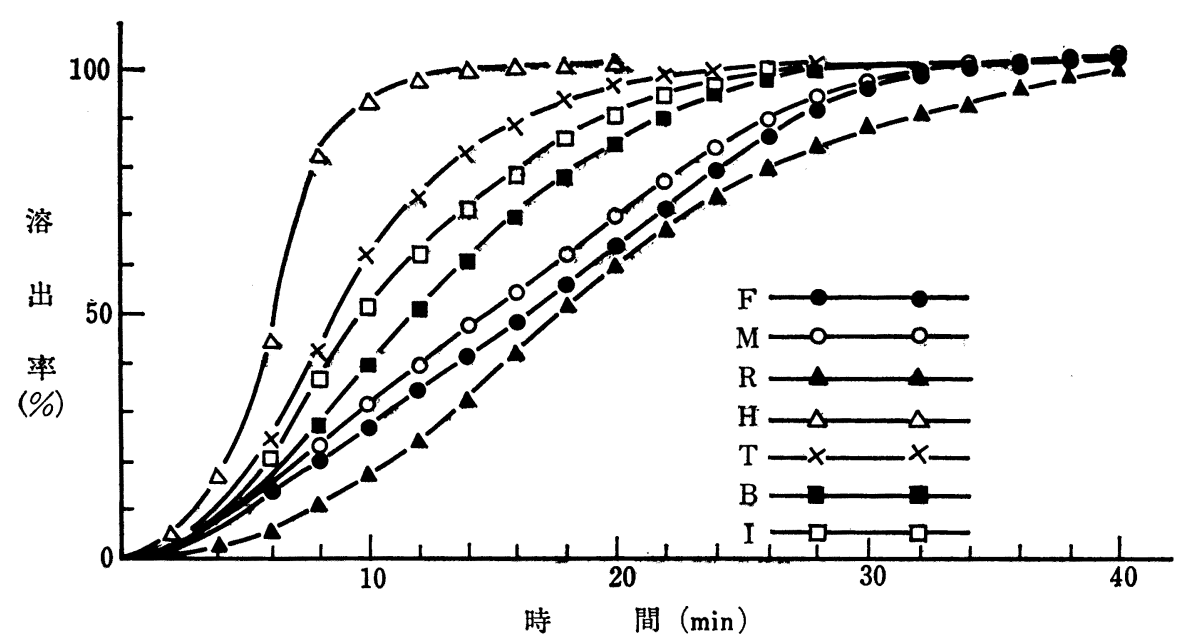

因 3. 水 $(\mathrm{pH} \mathrm{5.6)}$ 亿おける各銘柄の溶出曲線

較を目的とする上においては崩壊試験, 溶出試験す品質 管理面から十分に意味があると考えられる. 本実験の結 果からも同一成分, 同一含量, 同一剂形の各社製剤に打 いて，崩壊時間， $50 \%$ 溶出時間いずれも銘柄間に有意水 準 $5 \%$ で有意差が認められ，品筫管理上十分な検討と注 意が必要であると考える。
参考文部

1) 日局 9 : 第九改正日本薬局方, 広川書店 (1976).

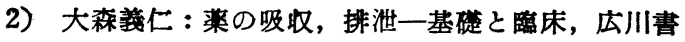
店 (1969).

3）花野 学: Bioavailability 研究資料, 日本メディ カルセンター, (1976)

生物学的末梢血管拡張剂

健保適用

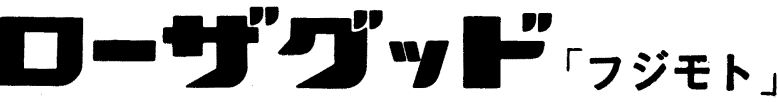 錠・カプセル}

すい臓抽出精製物50生物学的単位 を含み、循環系障害諸症に効果を もち、広範な自觉症状の改善を行 ないます。

\section{Fujimoto $>$ シ E}

詳紐については添付文書を参照下さい。

\section{包装}

錠：600錠 1200 錠 カプセル：600 cap. 1200cap.
藤本栔薬梣式会社

大阪市阿倍野区天王寺町北 2 丁目 6 番 7 每 工場: 大阪府松原市西大坏 1 丁目 3 番 40 号 $\bar{T} 580$ 電 話 $0723-32-5151$ (代) 